\title{
The Influence of the Climatic Factors on the Decay of Marbles: an Experimental Study
}

\author{
Paola Marini, Rossana Bellopede \\ DITAG - Dipartimento del Territorio, dell'Ambiente e delle Geotecnologie \\ Politecnico di Torino - C.so Duca degli Abruzzi 24, 10129 - Torino, Italy
}

\begin{abstract}
Stone decay is affected by the influence of climatic factors. In particular marble degradation, that could be expressed by decohesion and /or bowing, is mainly due to the action of temperature and water (rains and relative humidity). In this work non destructive and destructive tests have been performed to evaluate the decay of marble slabs subjected both to natural exposition and to artificial ageing tests (Lab - Bow test). Measurements of Ultrasonic Pulse Velocities (UPV) and bowing have been executed periodically on marble slabs exposed for a period of four years as preliminary field tests. On the base of this work an integrated test methodology to monitoring and previewing the behaviour of façade slabs have been set up. The methodology has been applied on the marble façade of modern building of centre Italy and consists of in situ and laboratory tests. In laboratory a destructive test (flexural strength) has been added to the non destructive tests to evaluate the decay before and after cycles of an ageing test. The results of the analysis, show an evaluative trend of the decay, though it changes its slope after 25 cycles of the ageing test. Moreover this work confirms the effectiveness of the employed non destructive tests and their god correlation with the mechanical tests.
\end{abstract}

Keywords: Marble, temperature, humidity, natural ageing, artificial ageing tests.

\section{INTRODUCTION}

In the recent 30 years the study of stone durability has reached great and great interest for both the scientific and technical community. Winkler in $1975^{[1]}$ focused on the weathering of stone in urban environment connecting to the causes and the potential problems on the use of stone in the structures. In the 1988 the marble façade slabs of Amoco Building in Chicago ${ }^{[2]}$ were replaced almost in total for safety reason. In the following years other famous buildings as Finlandia City Hall in Helsinky and La Gran Arche in Paris were subjected to marble façade slabs replacement.
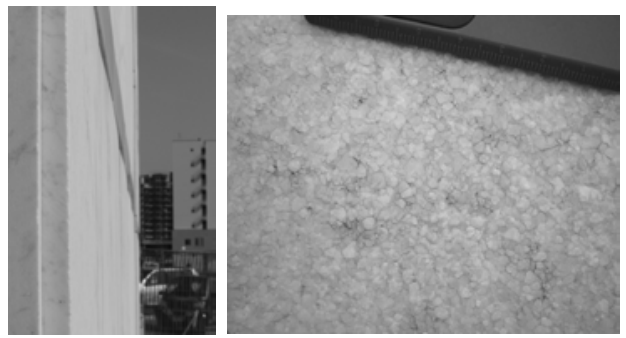

Fig. 1: Weathering of marble: bowing (on the left), decohesion (on the right).

Projects as McDUR and TEAM [3, 4], financed by European Community, in the last years have deepened the study on the durability of stone focusing on the causes and the evaluation methods of stone decay to prevent irremediable and dangerous damages.

Stones deteriorate in different ways; the weathered marbles, in particular, can show decohesion and bowing phenomena associated to a decreasing of mechanical properties (Fig. 1).

In the last 10 years many researches have been carried out in different countries to better understand the causes of the marble decay and its evolution.

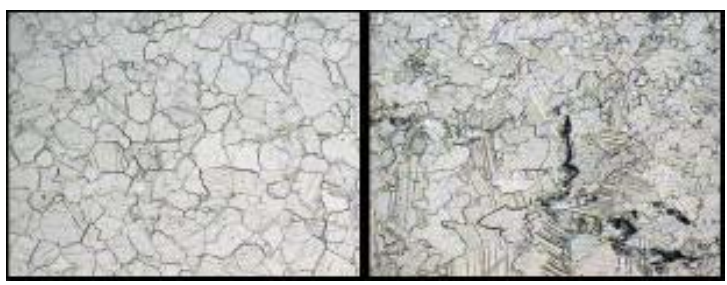

Fig. 2: Microphoto of a granoblastic marble (on the left) and a xenoblastic marble (on the right). Real dimensions $1,9 \times 2,5 \mathrm{~mm}$.

The composition and the microstructure of the stone influence the decay, and marbles (more the calcitic one rather than the dolomitic) are sensitive to thermal expansion because of anisotropic behaviour of calcite crystals $[5,6,7,8,9,10,11,12]$. Moreover, from the studies carried on by Royer Carfagni ${ }^{[13]}$ the relevance of the morphology of the grain boundaries was introduced, and it was confirmed by following works ${ }^{[14,15]}$. granoblastic marbles (idiomorphic habit) have higher

Corresponding Author: Paola Marini, DITAG (Dipartimento del Territorio, dell'Ambiente e delle Geotecnologie) Politecnico di Torino, c.so Duca degli Abruzzi 24, 10129 - Torino, Italy 
tendency to decay while xenoblastic (allotriomorphic habit) have lower (Fig. 2).

To sum up, intrinsic factor like mineralogy, texture, grain size, grain shape and boundaries of a stone are strictly connected with its resistance to modification (loss in mechanical strength, aesthetical variations, bowing, etc.) induced by external factors during its time of employment.

Concerning the climatic factors, measurements executed on building slabs show differences in the values of bowing at the different sides of the buildings $[16,17]$. This is connected with variations in insulation, wind pressure and humidity detectable at the different orientation of the slabs. Experimental works, included those performed within the EU projects TEAM and MCDUR, demonstrated that temperature variations can induce in marbles specimens residual strain $[15,18]$, loss of intergranular cohesion and consequently loss in mechanical strength. The presence of moisture make worse the performance of the stone too $[15,19]$, from the point of view of the residual strain induced by thermal expansion and in the mechanical strength too. It is commonly assumed that the mechanical resistance on saturated specimens gives lower results compared to the dried ones ${ }^{[20,21,17]}$.

Temperature changes on the wet stone lead to disruptive changes both after the freezing-thawing cycles ${ }^{[10,11]}$ and heating cycles ${ }^{[18,9]}$. The humidity is an important agent of decay and can influence the manifestation of bowing ${ }^{[21,9,15]}$.

Under the actions of the main climatic factor as temperature and moisture the façade marble panels are subjected to a progressive (may be exponential) weathering ${ }^{[9,22]}$.

This work relates on non destructive and destructive tests performed on the marble façade slabs of a modern building, where the bowing phenomenon is occurred, in order to establish the degree of weathering of the slabs and formulate a prevision on its evolution. This research has been possible thanks to the methodologies of analysis pointed out within the EU projects: studies on the effects of the climatic factors on the marble both in natural conditions and in laboratory after the execution of artificial ageing test.

The study on slabs exposed to natural ageing for a period of nearly four years is reported. These slabs were periodically tested by means of Non Destructive Tests (NDT) to evaluate the increasing of weathering taking into account the main factors influencing the measurements. These data were correlated with those coming from a destructive test performed in laboratory. From this preliminary research the guideline for an investigation methodology has been identified, and it was applied for the evaluation of the weathering degree of a building built in 1998 whose facades are totally clad in marble. In laboratory the execution of artificial ageing tests and disruptive tests, to assess the mechanical resistance before and after the weathering, permits to measure the effective loss resistance of the marble and to compare their results with the results of bowing and NDT (ultrasonic pulse velocity and water absorption measurements) performed in situ.

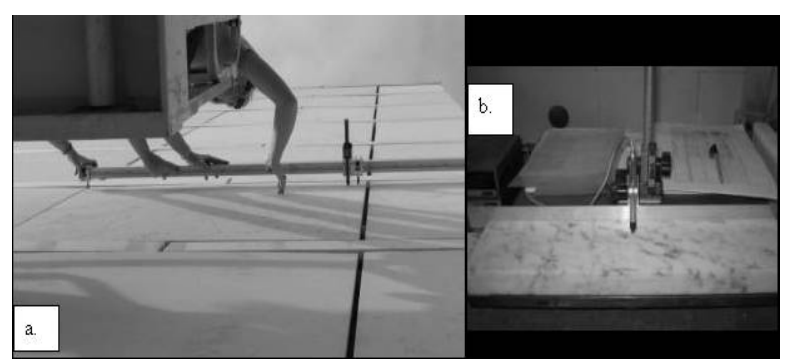

Fig. 3: a. In situ bow-meter - b. Laboratory bow-meter.

\section{MATERIALS AND METHODS}

\section{Bowing}

To measure the size of bowing two different methods have been used.

For the in situ measurements on the slabs a bow-meter designed and manufactured within the TEAM Project has been used, shown in Figure 3a. It is made of two aluminium elements that run along a graduated bar $168 \mathrm{~mm}$ long. Along the bow-meter a digital calliper, with a precision of $0,01 \mathrm{~mm}$, is placed on a mobile track able to reach every point along the bow-meter and measure the size of bowing of the slab.

The laboratory measurements have been performed by means of a digital micrometer calliper on a reference plane where the specimen is placed (Fig. 3b). The value of bowing is given in $\mathrm{mm} / \mathrm{m}$.

\section{Ultrasonic Pulse Velocity (UPV)}

The measure of UPV detects the physical-mechanical properties of the stone tested and it is a valid technique to assess the decay of a stone ${ }^{[10,23,24,25] .}$. The measures have been performed in indirect method following the EN 14579: 2004 Testing methods by means of the PUNDIT - CRO instrumentation connected with an oscilloscope software for lap-top. The transmitter and receiver transducers have a frequency of $33 \mathrm{kHz}$. The indirect method foresees the positioning of the transmitting transducer in the first point of an alignment while the receiver transducer is moved in subsequent points.

Water absorption by means of contact sponge (Wa) Measurements of water absorption have been executed by means of a not standardized method: a sponge (brand Spontex, type Calypso) made by natural fiber, cut with socket punch $55 \mathrm{~mm}$ diameter and seated in a plastic contact plate (1034 Contact Plate Rodac, brand Falcon). 
The sponge, completely dried, is saturated with distilled water to reach an initial saturated weight of the sponge and case $\left(\mathrm{m}_{\mathrm{i}}\right)$. The sponge is then positioned in contact with the stone surface for a lapse of time of $1 \mathrm{~min}$ exerting a constant pressure. Finally, the case is closed again and weighted to obtain the final weight $\left(\mathrm{m}_{\mathrm{f}}\right)$.

The result is express as the amount of water absorbed by the unity of surface in the unity of time, calculated as follow:

$$
W a=\frac{m_{i}-m_{f}}{23.76 \times t}
$$

where $W a=$ amount of water $\left(\mathrm{g} / \mathrm{cm}^{2} \mathrm{x} \min \right) ; m_{i}=$ initial mass $(\mathrm{g}) ; m_{f}=$ final mass $(\mathrm{g}) ; t=$ time of the contact between the stone surface and the sponge (min). The value of $23.76 \mathrm{~cm}^{2}$ represents the surface of the sponge. The measurements of UPV and Wa are efficacious to assess the decay of the stones and the correlation between their results is good [26, 27, 28].

\section{Flexural strength}

Flexural strength is the destructive methods that better reveals the decay of stone [29, 30]. Moreover it is well correlated with NDT such as UPV and water absorption $[25,31]$. The measure of flexural strength have been performed according to EN 12372:1999.



Fig. 4: Marble slabs toward West exposition. On the right of the picture the slabs exposed toward North.

\section{PRELIMINARY INVESTIGATION: LONG TERM EXPOSURE OF MARBLE SLABS AT POLYTECHNIC OF TURIN}

Several marble slabs have been located on a large terrace of the Politecnico di Torino, free from covers and far from the ground, positioned toward the four main orientations and have been inserted in a metal structure with interposition of rubber prisms to insulate the metal structure from the slabs, in order to prevent transmitting of the UPV signal (Fig. 4).

The slabs have been exposed from June 2003 and the weathering is still in progress. Measurements on these slabs have been performed according the steps in the Table 1.

Table 1: Steps of measurements executed on the slabs exposed on the terrace of the Politecnico di Torino.

\begin{tabular}{cccc}
\hline $\begin{array}{c}\text { N. of } \\
\text { measure }\end{array}$ & $\begin{array}{c}\text { Step of } \\
\text { measure }\end{array}$ & Date & Kind of measure \\
\hline 1 & T0 & April 2003 & Laboratory test \\
2 & T2 & June 2003 & In situ test \\
3 & T8 & December 2003 & In situ test \\
4 & T9 & January 2004 & Laboratory test \\
5 & T11 & March 2004 & In situ test \\
6 & T14 & June 2004 & In situ test \\
7 & T15 & July 2004 & Laboratory test \\
8 & T17 & September 2004 & In situ test \\
9 & T26 & June 2005 & In situ test \\
10 & T26 & June 2005 & Laboratory test \\
11 & T45 & January 2007 & Laboratory test \\
\hline
\end{tabular}

As in a previous study a correlation with the wind action was found [17], the attention has been focused on the slabs West orientated (maximum of insulation and wind force). Among the marble exposed, the Venato marble, coming from a Carrara quarry shows the higher decreasing of UPV results and increasing of bowing values. In the Figure 5 the data of UPV and bowing executed along the two diagonals are reported. The distance between the measurement points of UPV is $50 \mathrm{~mm}$. The bowing has been measured positioning the bow-meter (with a distance between the supports of $600 \mathrm{~mm}$ ) along the two diagonals with the calliper in the centre: the result is calculated as the mean of the two values measured for each slab in $\mathrm{mm} / \mathrm{m}$.



Fig. 5: UPV measurements (mean values) at different decay steps on two Venato marble slabs (West exposition).

The Venato marble shows a decreasing of UPV values already after 9 months of exposition and reaches $-48 \%$ after 45 months of exposition (Fig. 5). The measurements of bowing after 45 months of exposition show a different behaviour for the two slabs: Venato 1 has a convex bowing of $0,44 \mathrm{~mm} / \mathrm{m}$ while Venato 2 has a concave bowing of $0,62 \mathrm{~mm} / \mathrm{m}$, that is to say that both 
Table 2: Main climatic data for the period of exposition of the slabs on the terrace at Politecnico di Torino (data from www.swas.polito.it/services/meteo/)

\begin{tabular}{cccccccc}
\hline $\begin{array}{c}\text { Periods between consecutive } \\
\text { laboratory tests }\end{array}$ & $\begin{array}{c}\text { Months of } \\
\text { exposition }\end{array}$ & $\begin{array}{c}\text { Days with } \\
\mathrm{T}_{\max }>30^{\circ} \mathrm{C} \text { in } \\
\text { percent }\end{array}$ & $\begin{array}{c}\text { Days with } \\
\mathrm{T}_{\min }<0^{\circ} \mathrm{C} \text { in } \\
\text { percent }\end{array}$ & $\begin{array}{c}\text { Days with } \\
\text { solar radiation } \\
(\mathrm{SRmax}) \\
880 \mathrm{~W} / \mathrm{m}^{2} \text { in } \\
\text { percent }\end{array}$ & $\begin{array}{c}\text { Days with } \\
\text { Relative } \\
\text { Humidity } \\
\mathrm{RH}_{\max }>80 \% \\
\text { in percent }\end{array}$ & $\begin{array}{c}\text { Rainy days in } \\
\text { percent }\end{array}$ & $\begin{array}{c}\text { Days with } \\
\text { wind speec } \\
\max >6 \mathrm{~m} / \mathrm{s} \\
\text { percent }\end{array}$ \\
\hline April 2003 - January 2004 & 9 & 18 & 3 & 17 & 57 & 38 & 9 \\
January 2004 - July 2004 & 15 & 11 & 10 & 38 & 48 & 30 & 5 \\
July 2004 - June 2005 & 26 & 14 & 11 & 18 & 49 & 24 & 5 \\
June 2005 - June 2006 & 45 & 27 & 2 & 43 & 54 & 29 & 4 \\
\hline
\end{tabular}

the slabs suffered the decay but probably they were cut following different directions of the block.

In the Table 2 the main climatic data for the field exposure tests at the Politecnico di Torino are reported. For the last period of exposition the climatic data are available until June 2006. In the first 9 months of exposition, when there is a strong variation both of UPV and bowing measurement, there are higher percentage of rainy days, with $\operatorname{Tmax}>30^{\circ} \mathrm{C}$ and with higher wind speed than the other periods.

However, to study in controlled conditions and in few time the influence of climatic factors on the stone decay, artificially ageing tests have been performed in laboratory within a study performed on marble façade slabs of a modern building.

\section{THE CASE STUDY: THE MARBLE FAÇADE SLABS OF A MODERN BUILDING}

The measurement methodologies below exposed have been adopted to study the case of a modern building in centre of Italy where important bowing phenomena have been occurred on marble façade slabs. The slabs tested are of Carrara marble, mainly calcitic with a granoblastic structure (see Fig. 2). The slabs are placed with an anchoring system where a stiff bond has been erroneously produced by a resin on the back of the slab, to fix the dowel in the hole.

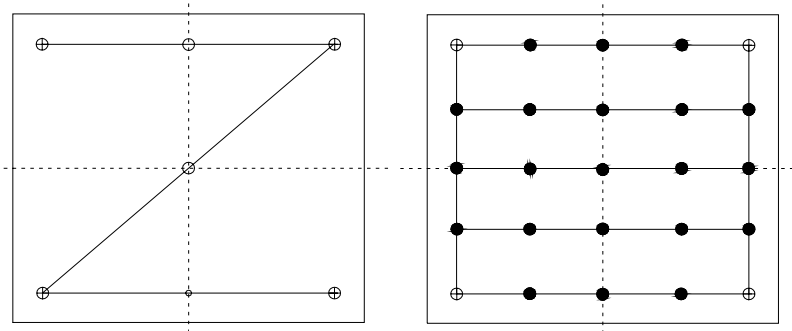

Fig 6: Measurement schemes of bowing in situ (on the left) and in laboratory (on the right). For the laboratory measurements the white circles indicate the points of support of bow-meter and the black one the points of measure.
The measurements of bowing by means of bow meter have been executed both in situ and in laboratory in accordance with the schemes reported in the Figure 6.

For the UPV measurements the points of measure have been positioned as in Figure 7 with a distance among them of $80 \mathrm{~mm}$.

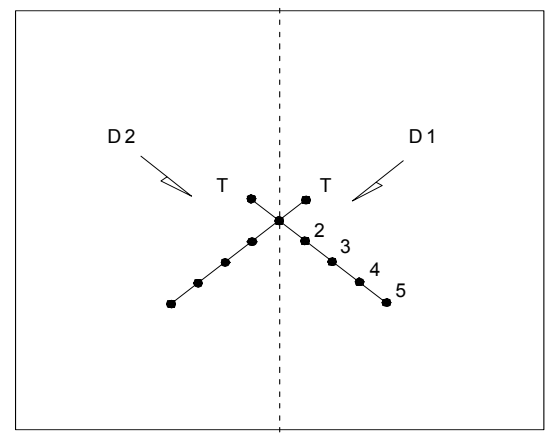

Fig. 7: Measurement scheme of UPV .

In situ measures of bowing, UPV and water absorption by means of contact sponge have been executed on 53 façade slabs. In laboratory flexural strength has been performed, together with the NDT, on marble specimens both at natural conditions and subjected to artificial ageing test (Lab- Bow test).

\section{In situ results}

The slabs oriented to S-E and S-W show an high spherical bowing ( $76 \%$ of slabs tested $\geq 6 \mathrm{~mm}$-Fig. 8 ), those on a turret show cylindrical bowing of mediumlow grade $(<6 \mathrm{~mm}-$ Fig. 9$)$ and, finally near to zero was the bowing for the internal and sheltered slabs.

In the Figure 10 and 11 respectively the correlations Bowing - UPV and - Bowing-Wa for the façade slabs S-E S-W are reported. With the increasing of bowing the UPV values decrease and the Wa increase.

The laboratory measurements

Flexural strength measurements executed in laboratory on specimens cut from façade slabs show that the slabs S-E-S-W oriented are $40-50 \%$ less resistant than the sheltered façade slabs. 


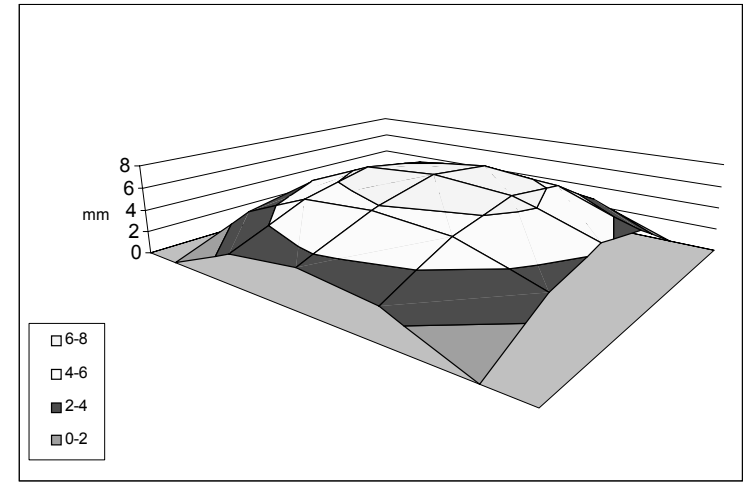

Fig. 8: Typical spherical bowing measured on S-E S-W exposed marble slabs of the modern building.

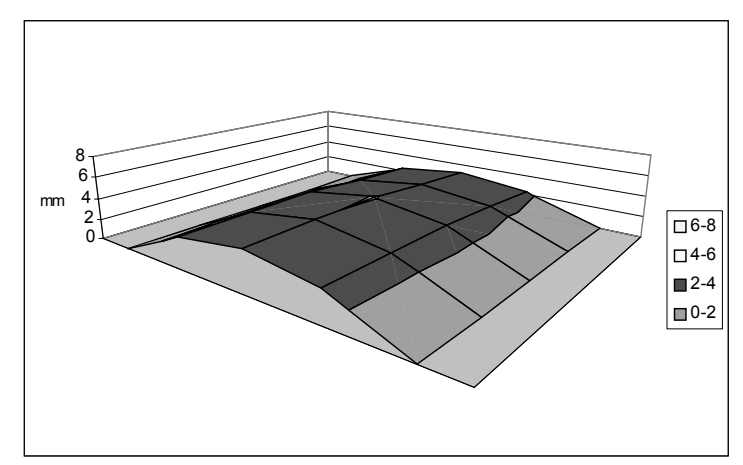

Fig. 9: Typical cylindrical bowing measured on marble slabs of the turret the modern building.

\section{The Lab- Bow Test}

To reproduce in laboratory the effects of water and temperature on the marble specimens the Lab- Bow Test has been carried out. It is a durability test and has been performed according to the North Test Method Build 4992002 Cladding panels test for bowing (Fig.12). The specimens of dimensions 400x100x30mm positioned on a wet sand and their upper face is heated by means of infrared lamps. During the cycle the temperature increases from $20^{\circ} \mathrm{C}$ to $80^{\circ} \mathrm{C}$ in 4 hours, it is kept constant for 3 hours and then it decreases to $20^{\circ} \mathrm{C}$ in 18 hours. The relative bowing is measured every cycle till the 5 and then every 5 cycles. A maximum of 50 cycles have been performed on 4 specimens cut from 2 different slabs. In particular the specimens named A are cut from a slab showing $5,5 \mathrm{~mm}$ of bowing in situ, while the specimens B are cut from a slab without bowing in situ.

In the figure 13 the data of bowing after Lab-Bow Test (LBT) on two different slabs of Carrara marbles (A and B) used on façade are reported.

The specimens subjected to LBT cycles have been tested by means of UPV in indirect method and then cut

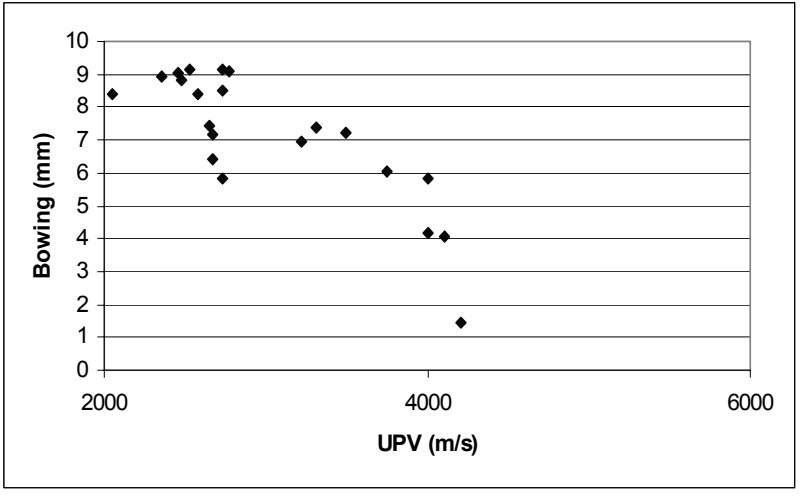

Fig. 10: Bowing versus UPV measurements for the marble façade slabs of a modern building exposed to $\mathrm{S}$ E-S-W.

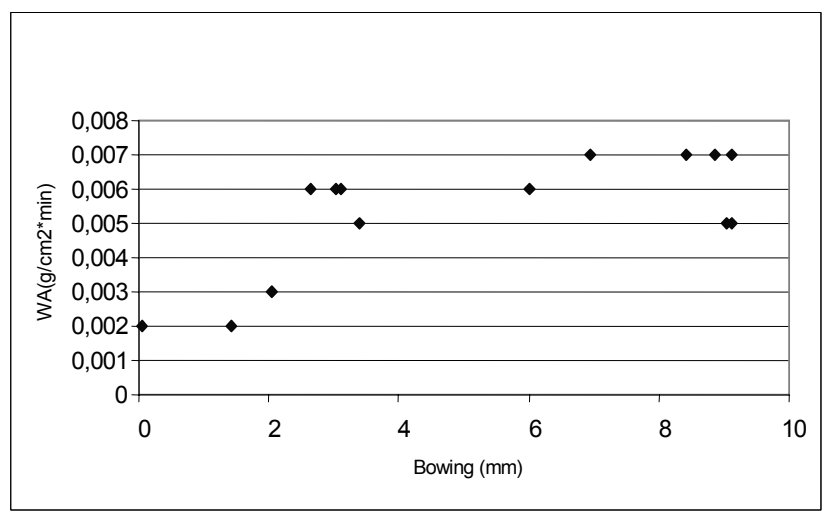

Fig. 11: Bowing versus Wa measurements for the marble façade slabs of a modern building exposed to SE-S-W.

to obtain from each four specimens of dimensions $180 \times 60 \times 30 \mathrm{~mm}$ for the flexural test.

In the Table 3 the mean values of UPV and flexural strength measured are reported.



Fig. 12: Apparatus for the execution of the Lab Bow test. 
Am. J. Environ. Sci., 3 (3): 143-150, 2007

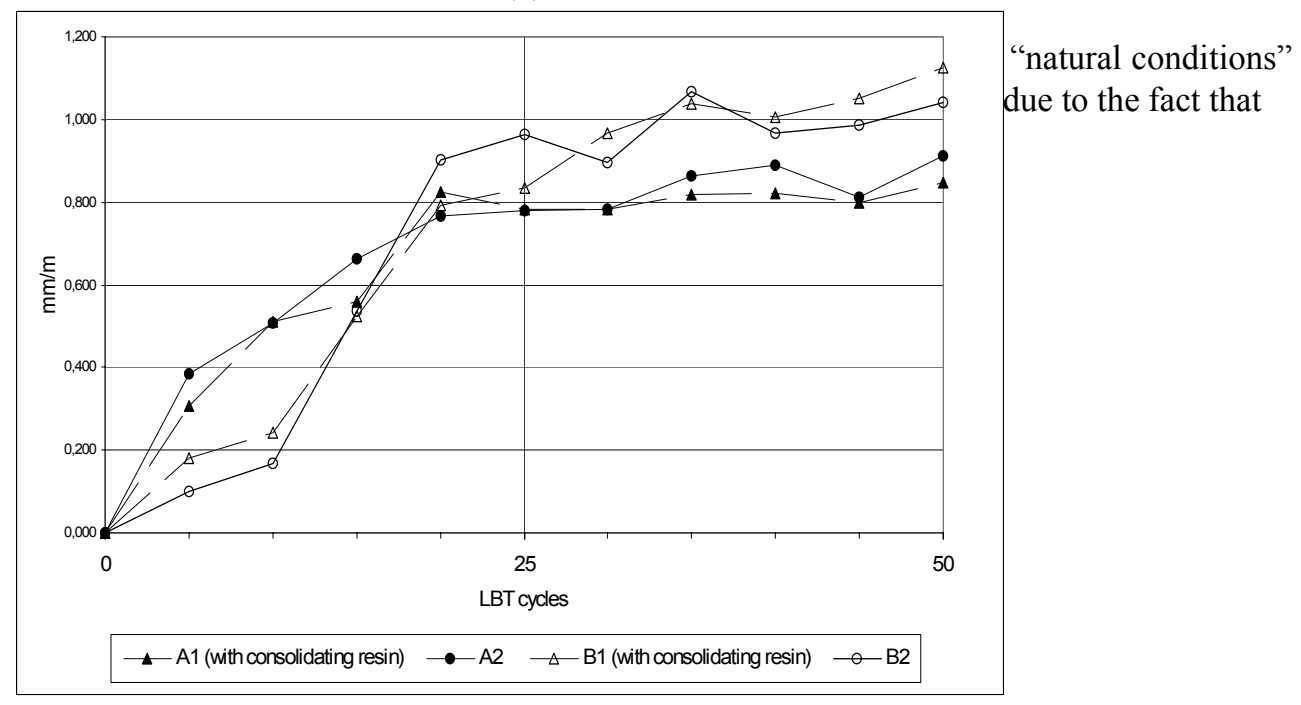

Fig. 13: Bowing measurements on specimens of Carrara marbles "A" and "B" after subsequent cycles of Lab - Bow Test.

\section{DISCUSSION AND RESULTS}

From the measurements executed in situ and in laboratory a series of consideration can be drawn:

- the correlation between bowing and mechanical resistance of the marble tested is clear. In fact the slabs with higher values of bowing reveal a decreasing of flexural strength values (until 40-50\%) respect those of the sheltered slabs;

- the slabs with higher bowing values are those oriented to S-E S-W. From the results obtained in the preliminary field tests, it is possible to assert that similar bowing conditions can be found for the other slabs of the building with the same exposition;

- the slabs placed in sheltered areas of the building show not only low bowing but even mechanical properties very similar to a new slabs;

- from the tests executed, the decreasing of mechanical resistance is well correlated with the increasing of water absorption and the decreasing of UPV. This is determined by a loss of cohesion of the grain and by an increasing of microcracks. Taking into account of these results, for the marble in object a critical values of Wa and UPV have been established respectively at 0.004 $\mathrm{g} / \mathrm{cm}^{2} \mathrm{x}$ min and at $3400 \mathrm{~m} / \mathrm{s}$.

The research highlights the bowing phenomenon as an evolutive mechanism and this is confirmed by the numerous artificially ageing cycles executed in laboratory. The slab A, that already bowed in situ, after 25 cycles decreases its trend to bowing (Fig. 13). The slab B, not already deformed in situ, reaches a higher bowing but shows the same trend o the slab A in the last 25 cycles. To confirm the bowing results, the UPV and flexural strength of slab B after 50 cycles hardly decrease compared to natural condition, while the this slab was subjected to decay on the façade, does not change despite the bowing.

Table 3:UPV and Flexural strength measurements for each slab A and B at natural condition and after 50 LBT cycles.

\begin{tabular}{lcc}
\hline \multicolumn{1}{c}{ Slabs tested } & UPV (m/s) & $\begin{array}{c}\text { Flexural } \\
\text { strength (MPa) }\end{array}$ \\
\hline $\begin{array}{l}\text { A0 (natural conditions) } \\
\text { A1 (after 50 LBT cycles - with } \\
\text { consolidating resin from 26 }{ }^{\text {th }} \text { cycle) }\end{array}$ & 2730 & 12,5 \\
A2 (after 50 LBT cycles - without & 2760 & 12,3 \\
$\begin{array}{l}\text { consolidating resin) } \\
\text { B0 (natural conditions) }\end{array}$ & 2370 & 11,5 \\
$\begin{array}{l}\text { B1 (after 50 LBT cycles - with } \\
\text { consolidating resin from 26 }\end{array}$ & 3120 & 18,9 \\
$\begin{array}{l}\text { B2 (after 50 LBT cycles - without } \\
\text { consolidating resin) }\end{array}$ & 2400 & 10,6 \\
\hline
\end{tabular}

On the base of the measurements executed and the results obtained, it is possible to affirm that the bowing phenomenon, after an initial increasing, grows steady and that the decay connected to mechanical resistance go on more and more slowly.

As consequence of this evaluation the following operative instructions have been suggested:

- to preview a systematic monitoring of marble façades, closer for the S-E S-W exposed and when critical values will found, a slabs should be take in laboratory to perform mechanical test;

- for the slabs with a bowing major than $5 \mathrm{~mm}$, to take precautionary action in order to reduce redundant bond that in few time can cause the collapse of the slabs; 
- for the sheltered places of the building, to perform the monitoring every $4-5$ years.

\section{REFERENCES}

1. Winkler E. M. 1975. Stone: Properties, Durability in Man's environment. Springer. Wien

2. Logan J. M. Hadedt M., Lehenert D., Denton M., 1993. A case study of the properties of marble as building veneer: International Journal of rock Mechanics, Mining Sciences and Geomechanics 30: $15310-1537$

3. McDUR EC Project. 2005. Final Report $\left(1^{\text {st }}\right.$ January $2004-31^{\text {st }}$ March 2005). Effects of the Weathering on Stone Materials: Assessment of their Mechanical Durability - McDUR (G6RDCT2000-00266).

4. TEAM EC Project 2005. Final Report Testing and Assessment of Marble and Limestone (GRD11999-10735)

5. Widhlam C., Tschegg E., Eppensteiner W. 1996. Anisotropic thermal expansion causes deformation of marble cladding: Journal of Performance of Constructed Facilities. 10:5-10

6. Leiss B. \&Weiss T. 2000. Fabric anisotropy and its influence on physical weathering on different types of Carrara marbles: Journal of Structural Geology 22: $1737-1745$

7. Siegesmund S., Ullemeyer K., Weiss T., Tschegg E. K. 2000. Physical weathering of marbles caused by anisotropic thermal expansion: International Journal of Earth Sciences 89: 170-182

8. Ferrero A. M. , Marini P. 2001Experimental studies on the mechanical behaviour of two thermal cracked marbles: Rock Mechanics and Rock Engineering 34 (1) , 57-66

9. Logan J. M. 2004. Laboratory and case studies of thermal cycling and stored strain on the stability of selected marbles: Environmental Geology. Springer-Verlag. 46: 456-467

10. Ondrasina J., Kirchner D. \& Siegesmund S. 2002. Freeze- thaw cycles and their influence on marble deterioration: a long term experiment in Natural Stone, Weathering Phenomena, Conservation Strategies and Cases Studies. Geological Society, London, Special Publication. 205. pp. 90-18

11. Ruedrich J. \& Siegesmund S. 2006 Fabric dependence of length change behavoiur induced by ice crystallisation in the pore space of natural building stones: Heritage Weathering and Conservation - Fort. Alvarez de Buergo, GomezHeras \& Vazquez-CAlvo (eds), Taylor \& Francis Group, London, 497-505

12. Siesgesmund S., Ruedrich J., Weiss T. 2004 Marble deterioration: Dimension Stone 20042004 14-16 June 2004 Prikryl ed. Praga. pp.211-217
13. Royer-Carfagni G. 1999. Some considerations on the warping of marble facades: the example of Alvar Aalto's Finlandia Hall in Helsinki: Construction and building materials 13 (1999) 449457

14. Alnaes L.,Koch A., Shouenborg B, Åkesson U. 2004. Influence of rock and mineral properties on the durability of marble panels: Dimension stone 2004, Prikryl

15. Koch A. \& Siegesmund S. 2004. The combined effect of moisture and temperature on the anomalous expansion behaviour of marble: Environmental Geology. DOI 10.1007/s00254004-1040. 46: 350-363

16. Malaga K., Schouenborg B., Alnaes L., Bellopede R. \& Brundin J.A. 2004 Field exposure sites and accelerated laboratory test of marble panels: Dimension Stone 2004 14-16 June 2004 Prikryl ed. Praga. 261-266

17. Luodes Ferraris N. M.2005.The bowing of marbleApproach through case histories and laboratory tests. $\mathrm{PhD}$ thesis, Politecnico di Torino 150p.

18. Malaga-Starzec K., Lindqvist Jan E. \& Schouenborg B. 2002 Experimental study on the variation in porosity of marble as a function of temperature: Natural Stone, Weathering Phenomena, Conservation Strategies and Case Studies. Geological Society, London, Special Publication, 205, 81-88.

19. Luodes N.M., Bellopede R., De Regibus C. \& Marini P. 2006. The influence of the humidity on the decay of marbles: Heritage, Weathering and Conservation. Fort, Alvarez de Buergo, GomezHeras \& Vazquez-Calvo (eds). Taylor \& Francis Group. 21 -24 June 2006London. ISBN 0-41541272-2. 491-496

20. Colback P.S.B. \& Wiid B.L. 1965 The influence of moisture content on the compressive strength of rocks: Proc 3rd Can Symp on Rock Mechanics, Toronto, Mines Branch, Dept pf Mines and Technical Surveys, Ottawa, pp.65-83

21. Winkler E. M. 1994 Stone in Architecture. Properties, Durability . Third Edition SpringerVerlag Berlin Heidelberg 313p.

22. Chau K.T. \& Shao J. F. 2006 Subcritical crack growth of edge and center cracks in façade rock panels subject to periodic surface temperature variations: International Journal of Solids and Structures. Elsevier Ltd ed. 43: 807-827

23. Christaras B. 2003. P-Wave velocity and quality of building materials: Industrial Minerals and Building stones, Instanbul, Turkey ISBN 975 92188 - 0- 1. pp.295-300 
24. Kourkoulis S. K., Prassianakis I., Agioutantis Z. \& Exadaktylos G. E. 2006. Reliability assessment of the NDT results for the internal damage of marble specimens Int. J. Materials and Product Technology 25 No. 1/2 Interscience Enterprises Ltd. 35-36

25. Bellopede R. \& Manfredotti L. 2006. Ultrasonic test on stone: comparison of indirect and direct methods under various test conditions: Heritage, Weathering and Conservation. Fort, Alvarez de Buergo, Gomez-Heras \& Vazquez-Calvo (eds). Taylor \& Francis Group. 21 -24 June 2006London. ISBN 0-415-41272-2. pp. 539-546

26. Manfredotti L. 2003. Indicatori del degrado dei materiali lapidei: Metodi e valutazione $\mathrm{PhD}$ thesis, Politecnico di Torino. 200p

27. Manfredotti L. \& Marini P. 2004 The "contact sponge": study of the applicability of a new and simple methodology: Heritage, Weathering and Conservation. Fort, Alvarez de Buergo, GomezHeras \& Vazquez-Calvo (eds). Taylor \& Francis Group. 21 -24 giugno 2006London. ISBN 0-41541272-2.
28. Bellopede R., De Regibus C., Manfredotti L. \& Marini P., 2005. Water Absorption and ultrasound pulse velocity to evaluate the decay of stones, in Non Destructive Investigations and Microanalysis for the Diagnostics and Conservation of the Cultural and Environmental Heritage, 15-19 May Lecce ISBN 88-89759-00-7

29. Frisa Morandini A., Mancini R., Gomez M., Comazzi G. 1989. Comportamento di manufatti in pietra nei riguardi degli agenti di degrado atmosferici: International Congress "Situazione e Prospettive dell'Industria Lapidea". Cagliari. pp.380-383

30. Marini P. 1994. Determinazione quantitativa del degrado delle pietre da decorazione e messa a punto di prove di invecchiamento accelerato per la previsione della loro durabilità. $\mathrm{PhD}$ Thesis. Politecnico di Torino, $132 \mathrm{p}$.

31. Bellopede R. 2006. La misura della velocità dell'impulso ultrasonico nella diagnostica e nel monitoraggio dello stato di conservazione delle pietre ornamentali. $\mathrm{PhD}$ thesis, Politecnico di Torino. $110 \mathrm{p}$. 